\title{
Female Entrepreneurship and Agritourism Cooperatives in the Greeк Periphery: An Overview
}

\author{
${ }^{1}$ Dimitrios Stavroulakis, ${ }^{2}$ Stefanos Karagiannis, ${ }^{3}$ Roido Mitoula, ${ }^{4}$ Aristides Papagrigoriou \\ ${ }^{1}$ Department of Accounting and Finance, Technical Educational Institute (TEI) of Piraeus, Athens, Greece \\ ${ }^{2}$ Department of Economic and Regional Development, Panteion University, Athens, Greece \\ ${ }^{3}$ Department of Home Economics and Ecology, Harokopion University, Athens, Greece \\ ${ }^{4}$ Department of Business Administration, Technical Educational Institute (TEI) of Piraeus, Athens, Greece
}

Received 2014-02-07; Revised 2014-03-07; Accepted 2014-03-13

\begin{abstract}
This study investigates the status of female entrepreneurs in the Greek countryside as formed in the recent years owed to the emergence of agritourism. Agritourism has provided opportunities for additional income in localities through the utilization of knowledge of traditional customs, recipes, folk art. Women entrepreneurs in the sector often function within a context of adverse circumstances, pertaining to their multiple responsibilities at home and at work. Organization of women in producers' cooperatives has facilitated their endeavor with regard to commitment, mutual support and pooling knowledge. On the other hand, major obstacles include lack of management education and insufficient marketing of local products. Even though status of women has been upgraded to an extent due to their additional contribution to the family income, conservative stereotypes about their role remain still intact in the countryside.
\end{abstract}

Keywords: Agritourism, Greece, Female Entrepreneurship, Agritourism Cooperatives, Women Farmers, Vocational Identity

\section{INTRODUCTION}

Employment in the agricultural sector is considered a "male" profession (Berlan-Darque, 1988; Haugen, 1990; Alston, 1995; Liepins, 1998), like the one of automobile repairer and the heavy machinery operator. According to long-standing, male-dominated stereotypes, male professions involve heavy work load and on the other hand technical skills that are considered beyond the biological limits of women. Nevertheless, the agricultural sector employs masses of women particularly in developing countries, e.g. in Southeast Asia more than $90 \%$ of workers in rice fields, in Kenya about $75 \%-89 \%$ in agricultural production, in Pakistan more than $80 \%$ in stock breeding and $60 \%$ in farming (Ahearn and Tempelman, 2010).

The vast majority of heads of agricultural properties throughout the world are men. For example, USA is considered the cradle of female entrepreneurship, since more than $40 \%$ of entrepreneurs are women. Nevertheless, according to the census of 2002, only 306, 209 principals of agricultural properties out of the total $2,100,000$ were women. These women were on average older than their male colleagues, a fact implying that a number of them undertook the family property after the death of their husband (Ahearn and Tempelman, 2010). In Austria $30 \%$ of farms are led by women but only $14.6 \%$ of representatives in agricultural chambers are female (Oedl-Wieser, 2005). Agricultural businesses run by women are on average smaller and less productive than those held by men. Nevertheless, differences in productivity are eliminated when comparing rural enterprises of equitable size and infrastructure (WBP, 2012).

Theoretically speaking, discriminations against women in salaried work might orient a large portion of them to an entrepreneurial career. Entrepreneurship

Corresponding Author: Dimitrios Stavroulakis, Department of Accounting and Finance,

Technical Educational Institute (TEI) of Piraeus, Athens, Greece 
entails independence and the capability on determining one's own working time and schedule. Female presence in the entrepreneurship arena per se constitutes an act of emancipation, entailing the negation of conservative perceptions that place women in house occupied with child-rearing, while men eke to supply the family income. Nevertheless, female entrepreneurship is not an easy path.

Ostensibly, the entrepreneur is capable of designing her own program and timetable. In real life, however, entrepreneurship usually requires excessive time and exhaustive effort, thereby alienating women from their family. Needless to say, protective legal devices for salaried women (maternity leave, child bounty etc) are not applicable to women entrepreneurs.

The financing system often does not trust women entrepreneurs, thereupon they are likely to face problems regarding approval of their investment proposals (Brush, 1992; Little and Jones, 2000). Research has shown that on average female entrepreneurs start with less capital than men, but they also create smaller debts than men (Warren-Smith et al., 2001; Weiler and Bernasek, 2001; Carter and Shaw, 2006).

Women entrepreneurs are confronted with prejudice and stereotypes in their business transactions. They face problems when attempting to establish relationships with professional groups (Warren-Smith et al., 2001), as well as in their effort to install sales networks (World Bank, 2012). On the other hand, a substantial number of women entrepreneurs are home-based in order to take care of children, a fact that might undermine their professional status.

Self-efficacy (Bandura, 1997; Boyd and Vozikis, 1994; Zhao et al., 2005) and risk-taking (Knight, 1921; Brockhaus, 1980; Carland et al., 1995; Wu and Knott, 2006) are fundamental traits of the entrepreneur. Research has shown that women take fewer risks and reach to more conservative decisions than men (Carter and Shaw, 2006; Niederle and Vesterlund, 2007). Among other reasons, inequitable presence of women in the entrepreneurship arena is also attributed to the shattering of their selfconfidence from the predominant male stereotypes (Brush et al., 2004).

A wide stream of research has focused on the peculiarities of female entrepreneurship and the comparison of traits and perceptions among female and male entrepreneurs (Marlow, 1997; Brush et al., 2004; Minniti and Naude, 2010; WBP, 2012). Research has pinpointed differences in perceptions regarding business development, the social role of business and the balance between work and family. According to the social feminism approach, the concept of business performance may be perceived in different ways, emanating from the different priorities of genders. Male entrepreneurs aim most of all at achieving concrete objectives and at maximizing profits. Female entrepreneurs, on the other hand, wish most of all to achieve balance between their professional and personal life (Marlow, 1997; Weiler and Bernasek, 2001). In this respect, Brush (1992) alleged that women entrepreneurs are more successful than men, since they are likely to achieve their own goals more easily. Research has also targeted the issue of business growth from the female perspective (Dalborg et al., 2011). Investigation of paradigms of successful women entrepreneurs demonstrated that their perception of business growth includes at a great extent the element of personal growth.

\section{THE SETTING}

In the last decades a massive migration of inhabitants of the countryside to cities had been witnessed in Greece. However, women (particularly the younger and unmarried ones) had been leaving their homeland at a greater extent than men. Nowadays, amidst the crisis, migration to cities has been discontinued. The following reasons prompting women away from homeland have been reported (Gidarakou-Kaffe, 1996).

Agricultural property in Greece is mostly segmented into small, unproductive lots, since inheritance follows the partibility pattern (Gidarakou et al., 2008; Koutsou et al., 2011). Work in cities used to be profitable, at least in the years before the economic crisis.

In farm households women are occupied mostly as non-salaried, auxiliary family members, meaning that they are financially dependent upon the household leader.

Rural work is particularly hard, women farmers being more encumbered than women of the city. Besides working in the fields and looking after their household, they also have to take care of the accommodation and nutrition of non-family farm workers (Rosenfeld, 1985).

Younger women in particular tend to believe that employment in agriculture is not rewarded enough and lacks social status and recognition. Educational opportunities in the recent years supplied women with skills enabling them to find better jobs in cities.

Predominant perceptions in the countryside reside on conservative roots, are particularly restrictive toward women and promote gender discrimination (Beggs et al., 1996).

Infrastructure in the countryside is occasionally problematic concerning e.g. scarcity of public transport, 
defective road network, telecommunications problems, intermittent electric power supply, lack of information, low effectiveness of public services etc. Lack of welfare institutions such as healthcare facilities and kindergartens may also be witnessed. Leisure and recreation activities are usually totally absent.

The decision of a woman to leave countryside depends both on intrinsic factors (age, education, existence of children) as well as on extrinsic ones (impact of the decision on the community, family attitude) (Gidarakou-Kaffe, 1996). In the recent years, migration to cities has largely subsided due to the financial crisis. Moreover, a number of unemployed people are in the process of turning back to their ancestral villages disregarding deficient infrastructures. Inadequate infrastructure explains also the lack of interest on the part of big companies in investing in rural areas, notwithstanding favorable legal devices and tax incentives. Although there do exist samples of success stories, there do exist business opportunities in the countryside, their exploitation is not an easy task. Unscheduled initiation of entrepreneurship in the hinterland entails considerable risk.

\section{LIFESTYLE ENTREPRENEURSHIP AND MULTIPLE VOCATIONAL IDENTITIES OF WOMEN}

Multi-employment, or polyvalent employment, is a common practice in Greek periphery. An individual may hold simultaneously jobs that may be irrelevant, or may be normally undertaken by different social strata, usually in order to minimize risks (Patiniotis and Stavroulakis, 1997). For example, a farmer at the same time may deal with agricultural property, run a small retail shop and let rooms for tourists. Pluriactivity is not necessitated solely due to the small size of lots that cannot provide substantial income through ordinary agricultural works. It may stem also from the fact that the farm is often inherited family property. Particularly women heirs rarely do consider farming as conscious vocational choice (Jervell, 1999), therefore they attempt to diversify. Diversification of rural activities through agritourism represents a radical change particularly for women, since it entails a departure from habitus and a transition to the contested terrain of entrepreneurship involving competition, initiative, uncertainty and toughness.

However, a substantial proportion of rural business may be classified as lifestyle entrepreneurship, through which farmers attempt to diversify activities in order to obtain an extra income, while at the same time satisfying needs of the family and retaining their own way of life. Work in agriculture is seasonal, apparently facilitating diversified activities around the clock. Lifestyle entrepreneurship constitutes the opposite pole of the Schumpeterian paradigm, its distinctive traits corresponding more to those of free-style self-employment than to rational business (Ateljevic and Doorn, 2000; Marcketti et al., 2006; Stavroulakis et al., 2008).

As happens also in other economic sectors, successful rural entrepreneurs are likely to start having already set concrete goals as well as possessing appropriate infrastructure, while the less successful ones usually become entrepreneurs out of necessity rather than ambition. Research among Finnish farmers showed that successful farmers/entrepreneurs had proceeded to the following (McElwee, 2005):

- Renovation of and investments in production

- Continuous development of vocational skills

- Self-confidence and eagerness to work hard if necessary

- Commitment to objectives and capability of goalsetting, achieving goals and setting new ones

- Utilization of the latest information relevant to business needs

- Networking and cooperation with professional groups

- On the other hand, the following features of lifestyle entrepreneurs have been reported (Peters et al., 2009)

- Motivation more by quality of life than growth. Sectors of rural business and tourism have been attracting a large number of small entrepreneurs who are not oriented to growth. In a research targeting Scottish farmers, about $86 \%$ declared that they did not wish growth of their business (Mochrie et al., 2006)

- Priority to lifestyle rather than to efficient customer service, according to tradeoff between leisure and workload

- Questionable viability of business

- Unwillingness to let go or sell the business

- Lack of training in business issues

- Distance from lobby organizations and power centers of the sector

- Absence of managerial rationality, which may be expressed among others through irrational decisionmaking, limited marketing and product development activities, underutilization of ICT technologies and low of appreciation of quality issues 
Despite viability problems, the role of lifestyle entrepreneurs in agritourism should not be downplayed. Their presence facilitates sustenance of local population to homeland, attracts tourists who wish to stay within a homely environment instead of impersonal mass tourism installations and contributes to the locality welfare. Moreover, in certain cases growth may not be undesirable if achieved e.g. through the establishment of synergies with other entrepreneurs and professionals (tour operators, contractors etc) (Irvine and Anderson, 2003), through participation in networks, as well as through exploitation of favorable legal provisions and absorption of EU subsidies (Peters et al., 2009).

Lifestyle entrepreneurs in agritourism are motivated primarily by intrinsic incentives, including social interaction between host and guests, providing information on rural issues, demonstrating traditional farming techniques to people of the city etc (Weaver and Fennel, 1997). Women in agritourism are motivated more by the need to aid their family, while profit is of secondary priority. Women respondents in a U.K. research stated that they started their business primarily in order to combine work with home obligations, while men did not report this reason at all (Marlow, 1997). The question is, whether working in different sectors all year long enables job holders to retain a single identity, or do they develop an "identity bricolage" Carruthers and Uzzi (2000), reported by Patiniotis and Prodromitis (2007) formed through their variform occupations. Within the context of family business, the boundaries between the home sphere and the working environment are rather confused. Ordinary work involves movement of the job incumbent from the private, familial space, to the public sphere of business. Consequently, especially in cases where work of women takes place at home, it is not perceived as "real work" either by male or female family members (Ioannidou and Nazou, 2006). Research in the island of Mykonos (Nazou, 2003) showed that women's entrepreneurial initiative in agritourism is often perceived by themselves more as an extension of their ordinary household duties that has to be carried out in parallel and less as a conscious vocational selection. In this respect, business and housekeeping rather complement than conflict one another.

\section{BUSINESS ACTIVITIES OF WOMEN IN GREEK COUNTRY SIDE}

Besides the ongoing economic crisis, another factor aiding to retain women at homeland concerns the emergence of new economic perspectives parallel to agriculture and stock-raising. These forms include the development of small business in the sectors of organic cultivations, floriculture, snails, agritourism and relevant fields (folk art, local recipes, ecotourism etc). New trends have appeared within the context of rejection of mass tourism products by consumers and their respective search for more healthy life patterns, e.g. through their sojourn in rural accommodations, their participation in traditional cultivation forms, their occupation with athletic activities in areas of natural beauties (horse-riding, kayak, hang-gliding) etc. (e.g., Hjalager, 1996; Butler, 1998; Karagiannis and Exarhos, 2006; Kizos and Iosifides, 2007).

Traditionally, Greek farmers had aimed first of all at covering their household needs and at a second phase at occasionally trading any product surplus. Therefore, entrepreneurial activities of Greek farmers had been underdeveloped, confined in selling their products to intermediaries, without establishing any direct connection with consumers. Farmers' interest has been rekindled recently due to the aforementioned business alternatives, to the decrease of their income stemming from agriculture and last but not least, to the curtailment of CAP subsidies. According to Eurostat about $30.3 \%$ of farm heads were women in Greece in 2007, compared to $25 \%$ in 2000 (reported by Koutsou et al., 2011). Even then, in many cases the woman's name on the business title is deceptive, applied in order to serve better the household interests (pocketing CAP subsidies, exploiting tax incentives, covering up for a male relative working elsewhere) (Anthopoulou, 2006; Gidarakou et al., 2006). In their research in the prefecture of Kilkis, where according to official data women in charge of their farm constitute $40 \%$ of the total, Koutsou et al. (2011) disclosed that from them only $38.3 \%$ were really occupied with agriculture and dealt with the management of their farm, the rest having nothing to do with rural work at all.

Alternative sources of income have made an appeal to a substantial number of women of the Greek countryside. Women tend to develop a more positive attitude towards entrepreneurship if they are capable of working within their community, or even better, at home (Anthopoulou and Koutsou, 2010; Breen and Karanasios, 2010). Consequently, demographic and social obstacles (illiteracy, poverty, ageing etc) often hindering women from pursuing a viable vocational career at the periphery may be mitigated through their activation in agritourism. Position of women has been upgraded through their transition from non-salaried, auxiliary family members to equitable business partners, who may be capable even 
of offering jobs to members of the wider family. In certain cases, a shift of power from male family members to female ones may be witnessed within the context of family business (Anthopoulou, 2006). Indeed, during peak seasons mobilization of the wider social network under female leadership is possible in order to respond to urgent orders (e.g. concerning preparation of pastries, traditional delicacies, textiles etc).

Despite increased participation of women in the family revenues and in decision-making, maledominated perceptions and stereotypes about their social role have not subsided-and there exist no signs indicating that they are going to (Ioannidou and Nazou, 2006; Galani-Moutafi, 1994). Patrimonial space has been imbibed by long-standing local customs and traditions and has been largely hostile to new migrants, thereupon has proved particularly recalcitrant to attempts for sociocultural change. In this respect, Anthopoulou and Koutsou (2010: 1714) underlined that.

"We should not overlook that fact that the professionalization of rural women's traditional female skills essentially reproduces gendered social stereotypes of female roles (nurturers, cooks and guardians of traditional values), in the final analysis undermining the same social and economic emancipation that emerges from active employment and a financial contribution to the family budget."

Intermittent process towards emancipation seems to be a common element among patriarchal societies. For example, in a research in rural Turkey Van Broeck (2001) found out that even though women occasionally were the ones who initiated the tourism venture, men came afterwards to assume leadership, as profits grew and business had to become more professional. The same research witnessed that position of women had been reinforced through their employment in tourism, but invariably they had to hand over their salaries to males.

As expected, occupation of women with rural entrepreneurship is possible only through low-risk activities which do not require substantial capital. Collective work in cooperatives (co-ops) is indicated due to the socio-economic context of localities, as well as to the demographic features of women. In 2008 had functioned about 140 agritourism co-ops in Greece employing about 3,000 women (Anthopoulou and Koutsou, 2010) (20-25 members on average), located mostly in mountainous areas and the islands; it is unclear, however, how many of these are inactive. These numbers are relatively small compared to the respective of neighboring countries (Italy, Turkey, Slovenia). Agritourism co-ops play an important role in improving quality of life in the countryside, since they contribute to moderation of poverty, to preservation of cultural heritage, to development of tourism, to increase of visitation and to elevation of the fame of localities. Advantages of women's organization in co-ops include the following (Kaldis et al., 2000; Theodoropoulou et al., 2008):

- Commitment of women to the common effort and dedication to success of their co-operative

- Provision of unpaid, overtime work according to demands

- Moderation of risk and uncertainty (that usually harasses private business) and mutual support of members, which is particularly needed at the beginning of the endeavor

- Combination of members' skills and strengths

- Creation of a valuable data base, formed through the accumulation of traditional knowledge on local products, customs etc

Nevertheless, women's co-ops, along with small agritourism business, are pestered by an array of problems, stemming often from absence of networking and synergies (Kazakopoulos and Gidarakou, 2003; Kizos and Iosifides, 2007), as well as from deficient education in business management, accounting, marketing and entrepreneurship principles (Gidarakou, 2005). There should be mentioned that marketing of local products is of particular importance due to the physical distance separating producers from consumers, consequently appropriate utilization of web applications and social media is of utmost priority (Kazakopoulos and Gidarakou, 2003; Che et al., 2005; Vakoufaris et al., 2007; Corinto and Curzi, 2010; Bouris et al., 2011; Karagiannis and Stavroulakis, 2011; Abel et al., 2013). In many cases agrifood products are not standardized, they bear no informative labels about their mode of production or origin of ingredients and they are not linked to the knowledge and know-how of the co-op (Vakoufaris et al., 2007).

In contrast to women entrepreneurs in urban centers who usually attend some preparatory seminars on entrepreneurial issues before starting-up, women of the countryside rarely had such an opportunity in the past (Iakovidou et al., 1999; Kazakopoulos and Gidarakou, 2003). In a recent research (Apostolopoulos, 2005) the majority of women members of agritourism co-ops declared that they had attended some form of relevant seminars, mostly through subsidized training programs (Gidarakou et al., 2006; Gidarakou et al., 2008). 
Notably, tourism activities require different skills and behaviors than those pertaining to farming (soft skills) and these have also to be taught, e.g. quality of services, politeness, communication, alacrity, negotiations and leadership (Koutsouris et al., 2013).

The situation is further aggravated owed to absence of co-ordination between agricultural, tourism and land use policies (Kizos and Iosifides, 2007; Koutsouris et al., 2013) -see also Dubois and Schmitz (2013) for similar problems in Wallonia. Institutional support remains a controversial issue regarding the Greek rural sector. In many cases the institution of CAP subsidies did not fulfill its purpose of renovating agricultural methods and production. Rather, by providing an effortless income it brought about inertia among farmers, flagging their motivation to innovate. Kizos and Iosifides (2007) criticized the distributive character of variform financial support programs on the grounds of providing financial aid of questionable feasibility to eligible agritourism units instead of being incorporated within a strategic plan at the heart of a rural development policy. In the previous decades, particularly in the $80 \mathrm{~s}$ and $90 \mathrm{~s}$, an effort had been made by the state to sustain non-viable co-ops through protectionist measures, such as guaranteeing prices of cereals, as well as determining artificially low interest rates regarding bank loans. On the other hand, till 2000 legislation had imposed state interventions in major issues concerning co-ops (auditing process, price-setting etc) thereby curtailing their autonomy. These malfunctions have been amended by law (Lamprinopoulou and Tregear, 2006).

The majority of members of women co-ops have no previous experience on business. They belong mostly to the age group between 36 and 55, are married with children and have finished the Gymnasium or the Lyceum (Gidarakou, 2005). Co-op members may be employed either on a full-time, or on a part-time basis (Vakoufaris et al., 2007). Comparative research between women leading agritourism co-ops and women in charge of private business in the tourism sector who participated in the Leader project showed that the former were on average elder and of lower educational background (Koutsou et al, 2009). On the other hand, agritourism coops are activated more in gastronomy and the culinary sector (traditional nutrition) while private business is more specialized in hospitality. Agritourism co-ops tend to start with less capital than private firms of the sector, a fact that besides the meager economic means of members may also be attributed to their orientation, presupposing different demands in capital (Kazakopoulos and Gidarakou, 2003; Koutsou et al.,
2009). Vakoufaris et al. (2007) pointed out that an important reason for women to form agrifood co-ops lies in the regulatory framework. While an ordinary food enterprise has to comply with strict specifications as regards to space, facilities, infrastructure, storage etc in order to obtain the operations license, a co-op is exempted from most of these prerequisites.

As happens in family business, in co-ops also members prefer not to jeopardize their endeavor by adopting hazardous strategies, out of insecurity and lack of professional skills. Iakovidou et al. (2006) found that risk aversion of women renders them reluctant to invest substantial personal capital in business as well as to pursue bank loans in order to expand, aiming mostly at exploiting subsidy programs (Kazakopoulos and Gidarakou, 2003; Vakoufaris et al., 2007). Most often, however, lack of capital is compensated through their hard, overtime work (Anthopoulou, 2006), or through utilization of heretofore unproductive property, e.g. transformation of derelict ancestral mansions into tourist installations (Galani-Moutafi, 1994). Women members have been found to foster low ambitions and to be satisfied even with a minimal profit, preferring to confine business activities within their community rather than assuming risks pertaining to strategic growth. Except entrepreneurial risks, business growth often requires hiring external specialized staff, a fact that might deteriorate human relations within the co-op, since mentalities of coop members and technocrats are entirely different.

Coming now to the effectiveness of agritourism and its impact to communities, diverse findings have been reported. Kizos and Iosifides (2007) in their research in the prefectures of Lesvos, Magnesia and Lefkada found total abstention from agritourism activities that are considered quite popular abroad (horse-riding, organized walks, organized participation of tourists in traditional agricultural and cattle-raising activities). They pinpointed the lack of differentiation of services, maintaining that small agrotourism units pertain more to "tourism" than to "agrotourism", by means of providing a parody of the same services that are offered by mass tourism providers. Another research in the North Aegean islands (Vakoufaris et al., 2007) stressed the dynamism of agritourism co-ops and their contribution to local economy, but also reported acute problems threating their viability such as limited member participation, lack of skills, insufficient marketing and amateurism. Anthopoulou and Koutsou (2010) witnessed substantial spread of agrifood co-op products among consumers. On the other hand, Symeonidou (2009) in her research in Central Macedonia observed neither worthwhile income 
increase of agrifood households, nor creation of new work positions, nor any significant positive outcomes to the economics of the community.

\section{CONCLUDING REMARKS}

Small-scale entrepreneurship in the Greek countryside has been rejuvenated to an extent due to the shift of a large portion of consumers from mass tourism products to a more healthy way of life. Since the woman of the countryside is often the protagonist of this endeavor, her status has been relatively upgraded, taking into account her previous inferior situation (Sinclair, 1997). She has embodied, among others, the properties of caretaker, the continuator of cultural heritage, the hostess, the conversant with traditional techniques, the guardian of authenticity, the housekeeper (Anthopoulou and Koutsou, 2010).

The latter property has multiple connotations in the Greek context. Literally, "housekeeping" (noikokyrosyne) encloses concepts like cleanness, tidiness and order. On the other hand, figuratively it refers to efficient administration of income yielded through honest and laborious work, as well as to the attaching family prosperity and prestige. In ordinary agricultural activities women deal only with the first dimension, as their contribution is confined in house. The second dimension, however, presupposes a more cooperative modus vivendi among genders within the context of agritourism family business, where all members have to contribute both skills and effort (Ioannidou and Nazou, 2006)-“it takes two to operate this kind of business" (Brandth and Haugen, 2007).

Women's co-ops seem to cover sufficiently consumer needs with regard to agritourism products. There should be mentioned, however, that small businesses and co-ops in the sector manage to survive within market niches which are left over by big enterprises (Kazakopoulos and Gidarakou, 2003; Dubois and Schmitz, 2013). Since the latter may attempt anytime to cover market niches of economic importance, small business ought to be prepared to defend themselves. Fundamental success preconditions for small rural business include promotion of their products, establishment of brand names and retention of high quality standards (Bouris et al., 2011). Kazakopoulos and Gidarakou (2003) mentioned that agritourism co-op venturing in market niches ought to become a group thinking process, involving participation of all stakeholders-women, youths, local authorities and other interested groups.
Differentiation of rural activities through agritourism entails to an extent conjunction of "male activities" (ploughing, digging) with "female" ones (cooking, cleaning, weaving). Nevertheless, gender roles remain distinct by and large in localities. Activation of women in agritourism has been conducted within the context of deep-rooted socio-cultural patterns in the direction of perpetuating gender inequalities. Despite the contribution of women to the household income, established perceptions about their role and status have not been negated so far. Therefore, opportunities for a radical renegotiation of their role leading to concrete emancipation through their occupation in agritourism appear rather limited.

\section{BIBLIOGRAPHY}

Abel, D.A., A. Bressan M. O' Shee and V. Krajsik, 2013. Website and social media usage: Implications for the further development of wine tourism, hospitality and the wine sector. Tourism Plann. Dev., 10 : 229-248. DOI: 10.1080/21568316.2012.747989

Ahearn, M.C. and D. Tempelman, 2010. Gender issues in agricultural and rural household well-being. Proceedings of the 3rd Global Conference on Agricultural and Rural Household Statistics, May 24-25, Washington, D.C., pp: 1-18.

Alston, M., 1995. Women on the Land: The Hidden Heart of Rural Australia. 1st Edn., UNSW Press, Kensington, ISBN-10: 0868403822, pp: 160.

Anthopoulou, T., 2006. Facets and dynamics of entrepreneurship of women of the countryside in the sector of food production: A preliminary approach. Proceedings of the 9th Pan-Hellenic Conference on Rural Economy, Nov. 2-4, Athens, Greek.

Anthopoulou, T. and S. Koutsou, 2010. Local agrifood products of women's cooperatives. Proceedings of the 9th European IFSA Symposium, Jul. 4-7, Vienna, Austria, pp: 1712-1720.

Apostolopoulos, K., 2005. Cases of female cooperative entrepreneurship in the alternative and soft tourism in the countryside. Proceedings of the 3rd Conference on Entrepreneurship, Innovating and Venturing, Dec. 15-16, Athens, Greek.

Ateljevic, I. and S. Doorn, 2006. 'Staying within the fence': Lifestyle entrepreneurship in tourism. J. Sustainable Tourism, 8: 378-392. DOI: $10.1080 / 09669580008667374$ 
Bandura, A., 1997. Self-Efficacy: The Exercise of Control. 1st Edn., Worth Publishers, New York, ISBN-10: 0716728508, pp: 604.

Beggs, J., V. Haines and J. Hurlbert, 1996. Revisiting the rural-urban contrast: Personal networks in nonmetropolitan and metropolitan settings1. Rural Sociol., 61: 306-25. DOI:10.1111/j.15490831.1996.tb00622.x

Berlan-Darque, M., 1988. The division of labour and decision-making in farming couples: Power and negotiation. Sociol. Ruralis, 28: 271-292. DOI: 10.1111/j.1467-9523.1988.tb00345.x

Bouris, J., P. Kaldis, G. Alexopoulos and A. Giannouzakou, 2011. Agricultural marketing competitive strategies and innovative practices in Greece. Technological Educational Institute of Athens.

Boyd, N.G. and G.S. Vozikis, 1994. The influence of self-efficacy on the development of entrepreneurial intentions and actions. Entrepreneurship Theory Pract., 18: 63-77.

Brandth, B. and M.S. Haugen, 2007. Gendered work in family farm tourism. J. Comparative Family Stud., 38: 1-14.

Breen, J. and S. Karanasios, 2010. Growth and expansion of women-owned home-based business. Int. Bus. Econom. Res. J., 9: 33-46.

Brockhaus, R.H., 1980. Risk taking propensity of entrepreneurs. Acad. Manage. J., 23: 509-520. DOI: $10.2307 / 255515$

Brush, C., 1992. Research on women business owners: Past trends, future directions and a new perspective. Entrepreneurship Theory Pract., 16: 5-30.

Brush, C., N.M. Carter, E. Gatewood, P.G. Greene and M. Hart, 2004. Clearing the Hurdles: Women Building High-Growth Businesses. 1st Edn., FT/Prentice Hall, Upper Saddle River, ISBN-10: 0131112015, pp: 270.

Butler, R.W., 1998. Rural recreation and tourism. In: The Geography of Rural Change, Ilbery, B. (Ed.)., Longman, Harlow, ISBN-10: 0582277248, pp: 211232.

Carland, J.W., J.W. Carland, J.A. Carland and J.W. Pearce, 1995. Risk taking propensity among entrepreneurs, small business owners and managers. J. Bus. Entrepreneurship, 7: 15-23.

Carruthers, B. and B. Uzzi, 2000. Economic sociology in the new millennium. Contemporary Sociol., 29: 486494.
Carter, S. and E. Shaw, 2006. Women's Business Ownership: Recent research and Policy Developments. University of Stirling.

Che, D., A. Veeck and G. Veeck, 2005. Sustaining production and strengthening the agritourism product: Linkages among Michigan agritourism destinations. Agric. Human Values, 22: 225-234. DOI: $10.1007 / \mathrm{s} 10460-004-8282-0$

Corinto, G.L. and F. Curzi, 2010. Rural development and social network sites: A case study in Marche region (Central Italy). Tourism Today, 10: 23-39.

Dalborg, C., Y. Friedrichs and J. Wincent, 2011. Leaving the numbers behind: Qualitative growth, business platforms and motivation of women entrepreneurs. Proceedings of the 56th Annual ICSB World Conference, Jun. 16-16, Stockholm, pp: 1-26.

Dubois, C. and S. Schmitz, 2013. What is the position of agritourism on the Walloon tourist market? Eur. Countryside, 5: 295-307. DOI: 10.2478/euco-20130019

Galani-Moutafi, V., 1994. From agriculture to tourism: Property, labor, gender and kinship in a Greek Island village (part two). J. Modern Greek Stud., 12: 113-131. DOI: $10.1353 / \mathrm{mgs} .2010 .0233$

Gidarakou-Kaffe, I., 1996. Labor Relations in Agricultural Property: Status and Perspectives of Female Presence. 1st Edn., Athens: Papazissis.

Gidarakou, E., 2005. Women's co-operative entrepreneurship in the rural sector. Proceedings of the 3rd Conference on Entrepreneurship, Innovating and Venturing, Dec. 15-16, Athens.

Gidarakou, E., E. Dimopoulou, L. Kazakopoulos and A. Koutsouris, 2006. Gender and professionalism in agriculture. Proceedings of the 9th Pan-Hellenic Conference on Rural Economy, Nov. 2-4, Athens.

Gidarakou, I., L. Kazakopoulos and A. Koutsouris, 2008. Tracking empowerment and participation of young women farmers in Greece. In: Gender Regimes, Citizen Participation and Rural Restructuring, Morell, I.A. and B. Bock (Eds.)., JAI Press, Amsterdam, pp: 143-166.

Haugen, M., 1990. Female farmers in Norwegian agriculture from traditional farm women to professional female farmers. Sociologia Ruralis, DOI: $10.1111 /$ j.146, 30: 197-209.

Hjalager, A.M., 1996. Agricultural diversification into tourism: Evidence of a European Community development programme. Tourism Manage., 17: 103-111. DOI: 10.1016/0261-5177(95)00113-1 
Iakovidou, O., T. Anthopoulou and K. Triantafyllou, 1999. Innovative action of rural women in an upcountry region the case of the women's agrotourism cooperative of Agios Germanos. Proceedings of the International Conference: Gender and Rural Transformations in Europe: Past, Present and Future Prospects, Oct. 14-17, Wageningen.

Ioannidou and D. Nazou, 2006. Between tourism, olives and the household: Women entrepreneurship in Petra and Molyvos of Lesvos. Proceedings of the 9th Pan-Hellenic Conference on Rural Economy, Nov. 2-4, Athens.

Irvine, W. and A.R. Anderson, 2003. Small tourist firms in rural areas: Agility, vulnerability and survival in the face of crisis. Int. J. Entrepreneurial Behav. Res., 10: 229-246. DOI: 10.1108/13552550410544204

Jervell, A.M., 1999. Changing patterns of farming and pluriactivity. Sociologia Ruralis, 39: 100-116. DOI: 10.1111/1467-9523.00095

Kaldis, P., E. Theodoropoulou, G. Alexopoulos and A. Giannouzakou, 2000. Agritourism and development. Pedagogic Institute, Athens.

Karagiannis, S. and G. Exarhos, 2006. Tourism Herakleion: The Centre for Technological Research of Crete, CTR-Crete Publications.

Karagiannis, S. and D. Stavroulakis, 2011. Developing of agrotourism through the application of internet technologies: Problems and perspectives. Proceedings of the 5th International Conference on Information and Communication Technologies in Agriculture, Food and Environment (HAICTA): Sept. 8-11, Skiathos, pp: 299-308.

Kazakopoulos, L. and I. Gidarakou, 2003. Women's cooperatives in Greece and the niche market challenge. J. Rural Cooperat., 31: 25-45. Kizos, T. and T. Iosifides, 2007. The contradictions of agro tourism development in Greece: Evidence from three case studies. South Eur. Society Polit., 12: 5977.

Knight, F.H., 1921. Risk, Uncertainty and Profit. 7th Edit., Houghton Mifflin Co., New York, pp: 381.

Koutsou, S., O. Notta, V. Samathrakis and M. Partalidou, 2009. Women's entrepreneurship and rural tourism in Greece: Private enterprises and cooperatives. South Eur. Society Polit., 14: 191-209. DOI: 10.1080/13608740903037968

Koutsou, S., M. Partalidou and M. Petrou, 2011. Contemporary reading of family farming in Greece. Sociologia Ruralis, 51: 404-419. DOI: 10.1111/j.1467-9523.2011.00541.x
Koutsouris, A., I. Gidarakou, M. Kokkali and M. Dimopoulou, 2013. Agrotourism in opposition to agriculture? In: Fertile Links? Connections between Tourist Activities, Socioeconomic Contexts and Local Development, Figuereido, E. and A. Raschi (Eds.)., Firenze University Press, Firenze, pp: 145169.

Lamprinopoulou, C. and A. Tregear, 2006. Agrifood SMEs in Greece: The role of collective action. British Food J., 108: 663-676. DOI: 10.1108/00070700610682346

Liepins, R., 1998. The gendering of farming and agricultural politics: A matter of discourse and power. Australian Geographer, 29: 371-388. DOI: $10.1080 / 00049189808703230$

Little, J. and O. Jones, 2000. Masculinity, gender and rural policy. Rural Sociol., 65: 621-639. DOI: 10.1111/j.1549-0831.2000.tb00047.x

McElwee, G., 2005. Developing entrepreneurial skills for farmers. Report for the European Commission.

Marcketti, S., L.S. Niehm and R. Fuloria, 2006. An exploratory study of lifestyle entrepreneurship and its relationship to life quality. Family Consumer Sci. Res. J., 34: 241-259. DOI: 10.1177/1077727X05283632

Marlow, S., 1997. Self employed women-new opportunities, old challenges? Entrepreneurship Regional Develop., 9: 199-210. DOI: 10.1080/08985629700000011

Minniti, M. and W. Naude, 2010. Introduction: What do we know about the patterns and determinants of female entrepreneurship across countries? Eur. J. Dev. Res., 22: 277-293.

Mochrie, R., L. Galloway and E. Donnelly, 2006. Attitudes to growth and experience of growth among Scottish SMEs. Int. J. Entrepreneurial Behaviour Res., 12: 7-20. DOI: 10.1108/13552550610644454

Nazou, D., 2003. Multiple identities and their representation in a tourist island of Cyclades. $\mathrm{PhD}$ Thesis, Department of History and Social Anthropology, Aegean University.

Niederle, M. and L. Vesterlund, 2007. Do women shy away from competition? Do men compete too much?. Quarterly J. Econom., 122: 1067-1101. DOI: 10.1162/qjec.122.3.1067

Oedl-Wieser, T., 2005. Blind spots' of rural development policy in Austria from a gender-equality perspective. Proceedings of the 21th ESRS Congress: A Common European Countryside? Change and Continuity, Diversity and Cohesion in the Enlarged Europe, August 22-27, Keszthely (Hungary). 
Patiniotis, N. and G. Prodromitis, 2007. The 'double' vocational identity of the working population in the Greek tourist industry. In: Identities at Work, Brown, A., S. Kirpal and F. Rauner (Eds.)., Springer, 90-114, Frankfurt am Main.

Peters, M., J. Frehse and D. Buhalis, 2009. The importance of lifestyle entrepreneurship: A conceptual study of the tourism industry. Revista de Turismoy Patrimonio Cultural, 7: 393-405.

Rosenfeld, R.A., 1985. Farm Women: Work, Farm and Family in the United States. 1st Edit., University of North Carolina Press, Chapel Hill. ISBN-10: 0807841935, pp: 368.

Sinclair, T., 1997. Gendered work in tourism: Comparative perspectives. Gender, Work and Tourism, 1st Edit., Routledge, London, ISBN-10: 0415109868, pp: 244

Stavroulakis, D., P. Kalantonis, C. Oikonomou and K. Mavreas, 2008. Social capital, small business and entrepreneurship in Messinia. Arch. Economic History, 20: 113-137.

Symeonidou, P., 2009. Competitiveness and viability of agritourism business in Greece. $\mathrm{PhD}$ Thesis, Aristotle University.

Theodoropoulou, H., R. Mitoula, O. Astara and P. Kaldis, 2008. Applied issues of agritourism cooperation and sustainable endogenous development. Am. J. Applied Sci., 5: 1588-1594.

Vakoufaris, H., T. Kizos, I. Spilanis, M. Koulouri and A. Zacharaki, 2007. Women's cooperatives and their contribution to the local development of the North Aegean region, Greece. J. Rural Cooperat., 35: 1941.
Van Broeck, A., 2001. Pamukkale: Turkish homestay Tourism. In: Hosts and Guests Revisited: Tourism Issues of the 21st Century, Smith, V. and M. Brent (Eds.)., Cognizant, New York, pp: 161-174.

Warren-Smith, I., A. Monk and S. Parsons, 2001. Women in micro-businesses: Pin money or economic sustainability for rural areas? Proceedings of the Conference The new Challenge of Women's Role in Rural Areas, Oct. 4-6, Agricultural Research Institute in Nicosia, Cyprus.

Weaver, D.B, 1997. The Vacation farm sector in Saskatchewan: A profile of operations. Tourism Manage., 18: 357-365. DOI: 10.1016/S02615177(97)00039-3

Weiler, S. and A. Bernasek, 2001. Dodging the glass ceiling? Networks and the new wave of women entrepreneurs. Soc. Sci. J., 38: 85-103. DOI: 10.1016/S0362-3319(00)00111-7

WBP, 2012. Gender Equality and Development. World Bank Publications

$\mathrm{Wu}$, B. and A. Knott, 2006. Entrepreneurial risk and market entry. Manage. Sci., 52: 1315-1330. DOI: $10.1287 / \mathrm{mnsc} .1050 .0543$

Zhao, H., S.E. Seibert and G.E. Hills, 2005. The mediating role of self-efficacy in the development of entrepreneurial intentions. J. Applied Psychol., 90: 1265-1272. DOI: 10.1037/0021-9010.90.6.1265 